\title{
SAMULI HURRI
}

\section{OIKEUS \& JÄRKI}

Tiede E edistyksen tässä numerossa käsitellään Platonia ja oikeusfilosofiaa. Artikkelit ovat syntyneet noin vuoden kestäneessä poikkitieteellisessä tutkijatyöpajassa. Työpajan taustalla on laajempi Platonin oikeusfilosofiaa tutkiva Miettimö-hanke. Miettimö järjesti joulukuussa 2001 "Oikeus ja järki" -symposiumin, johon osallistui noin 50 eri humanististen alojen tutkijaa. Symposiumin esitelmät ovat olleet pohjana nyt julkaistaville kirjoituksille.

Antiikin teksteistä kiinnostuu oletettavasti ihminen, joka ei täysin viihdy omassa ajassaan. Platonin kirjoitukset taas puhuttelevat ehkä sellaista, joka ei viihdy sen paremmin nykyisyydessä kuin menneessäkään. Hän arvelee tunnistavansa lukukokemuksessa jotain yleispätevää ja ikuistakin. Platonin monimielinen ajattelu ei suoraan alistukaan välineeksi ajan muuttuville tarpeille. Platonin teksti valloittaa edelleen myös kirjallisuutena, monitasoisena kerrontana ja uskottavina ja uskomattomina sankareina, vaikka lähes 2400 vuotta on kulunut.

Platon on niin ajaton, että ei olisi tyylikästä ruveta esittelemään, kuinka ajankohtaisia platoniset aiheet ovatkaan juuri tällä hetkellä. Nykylukijalla ei ole yhtään entistä parempaa syytä lukea Platonista kirjoitettuja artikke- leita; tämä koskee myös oikeusfilosofiaa.

Eräs oikeusfilosofian ikivihreistä kysymyksistä on legitiimi vaihtoehto pelkälle voimapolitiikalle. Dialogissa Valtiomies Platonin elealainen vieras päätyy ehdottamaan järjestelyä, jota nykyisin kutsumme oikeusvaltioksi. Oikeusvaltiota hallitaan sellaisten lakien mukaan, jotka alamaiset hyväksyvät vapaaehtoisesti. Vallankäytön hyväksyttävyyden ongelma siirtyy tällä tavalla kuitenkin vain eteenpäin lakien hyväksyttävyyden ongelmaksi, minkä Platon hyvin tiesi.

Kysymys voimapolitiikasta ja hyväksyttävästä vallankäytöstä saa erään oikeustieteellisen ilmaisun luonnonoikeudellisen periaatteen (veritas non auctoritas facit legem) sekä positivistisen periaatteen (auctoritas non veritas facit legem) välisenä kiistana. Siinä on kysymys oikeuden ylipositiivisista elementeistä, jotka ovat kaiken neuvottelun, sopimisen ja lainsäätämisen tavoittamattomissa. Onko jotain, joka on ymmärryksen eikä tahdon varassa? Mikä takaa, että se jokin ei pelkästään oikeuta olevia oloja vaan toimii myös kritiikin mittapuuna? Jos oikeusjärjestys on viimeinen linnake mielivaltaa vastaan, niin mistä tulee oikeusjärjestyksen itsensä oikeudenmukaisuus?

Näitä kysymyksiä varten Tiede E edistyk- 
sessä oli teemanumero edellisen kerran 14 vuotta sitten (4/88). Tuon numeron avauksessa Kaarlo Tuori kirjoitti aiheesta Jürgen Habermasia tulkiten seuraavasti: "Myös poliittisen alueella Järjen on määrä kesyttää Valta, ja tämä tapahtuu Vallan Legitimiteetin takaavan Oikeuden avulla; Oikeuden on määrä ruumiillistaa Järkeä. Vallan vastapainoksi saamme yhtälön Legitimiteetti $=$ Oikeus $=$ Järki" (s. 261). Vuoden 1988 jälkeen tiede on edistynyt huimasti ja maahan on muun muassa säädetty uusi perustuslaki, puhumattakaan kaikesta muusta aiheeseen liittyvästä, maailmassa tapahtuneesta ja koko ajan tapahtuvasta.

Käsillä olevassa numerossa pohdiskeluja ei kuitenkaan jatketa tältä pohjalta, aksioomista eteenpäin, niin kuin Platon sanoo matemaatikkojen tekevän. Sen sijaan teemme niin kuin platoniset dialektikot ja palaamme takaisin lähtökohtiin ja jatkamme vielä pitkälle siitä taaksepäin, ainakin aatehistoriallisesti. Tarkoituksena on mennä Järjen varaan kasvaneen poliittisen ymmärryksen alkulähteille Platoniin, jonka ajattelussa Järjelle alistettu valtio oli olevien olojen kritiikki, ei niinkään toteuttamiskelpoinen vaihtoehto.

Miettimössä huomion kohteena ei ole ollut se, mitä Platon järkevästi perustellen sanoo yhteiskunnasta tai sen hallinnon hyvästä ja huonosta järjestämisestä. Ennemmin olemme etsineet sitä paikkaa, jonka itse järki saa Platonin oikeusfilosofisissa teksteissä. Taustalla on luonnollisesti myös latentti kysymys siitä, sopiiko järki samalle paikalle myös "oikeasti toteutettavissa" yhteiskunnassa. Miettimössä on työstetty varsin erilaisia lukutapoja Platonin teksteihin ja tämä näkyy myös nyt julkaistavissa kirjoituksissa. Tästä huolimatta keskusteluyhteys on säilynyt ja tekstit viittaavat toisiinsa, vaikka jokainen kirjoittaja selvästi sijoittaa Platonin oman ajattelunsa kontekstiin.

Miettimö-työpaja kiittää yhteisesti kaikkia Oikeus ja järki -symposiumiin osallistuneita hyvästä keskustelusta ja kriittisistä huomioista. Erityinen kiitos kuuluu kanssamme työskennelleille Lars D. Erikssonille, Ari Hirvoselle, Marja-Liisa Kakkuri-Knuuttilalle, Simo Knuuttilalle, Kevät Nousiaiselle, Holger "logos elää!" Thesleffille sekä Miettimön opiskelijajäsenille oikeustieteellisessä tiedekunnassa. Tiede $\varepsilon$ edistystä kiitämme kirjoituksien julkaisemisesta ja Suomen Kulttuurirahastoa taloudellisesta tuesta. 